\title{
Review Essay
}

\section{Fighting the State}

\section{Wolfgang Streeck}

Quinn Slobodian, Globalists: The End of Empire and the Birth of Neoliberalism. Cambridge, MA: Harvard University Press, 2018. 400 pp. $£ 25.95$ hardcover.

Neoliberalism, we learn from this truly eye-opening book, is not new at all; it is, in fact, almost a century old. Why 'neo', then? Because it was conceived and intended to promote the return of the stateless liberal Weltwirtschaft (the globally integrated world economy of the gold standard) which even Karl Polanyi sometimes celebrated with a note of nostalgia. Conceived it was by an identifiable, and now precisely identified, group of people who carried it and the project it stood for to its, however preliminary, victory in our time. The end of liberalism and the rise of neoliberalism began in 1918, with the fall of the empires of free trade and their replacement with a host of sovereign and potentially democratic nation states, carriers of a dangerous virus called 'economic nationalism'. After 1945 followed decolonization and the introduction of majority voting in the General Assembly of the United Nations - anti-liberal political architectures which, together with the Keynesian gospel of national self-sufficiency, threatened not just economic progress but also, this was the claim, the open society, human freedom and dignity. Hence the prefix 'neo'.

Contemporary literature on neoliberalism works with many, more or less mutually compatible definitions, and there is no need to discard any of them out of hand. Still, in the sense in which Slobodian pursues the concept back to its origins, we can now use it with so much more confidence and precision. Neoliberalism, in short, is about the desirability and possibility of a return to a kind of liberal cosmopolitanism that Adam Smith described in his analysis of the rise of capitalism (in other words, the ownership of 'stock') in an early modern, still borderless Europe:

The proprietor of stock is necessarily a citizen of the world, and is not necessarily attached to any particular country. He would be apt to abandon the country in which he was exposed 
to a vexatious inquisition, in order to be assessed to a burdensome tax, and would remove his stock to some other country where he could either carry on his business, or enjoy his fortune more at his ease. (Smith, 1776/1999: 442)

Restoring stock owners' cosmopolitan paradise required sophisticated intellectual, ideological and institutional manoeuvres - the relentless, untiring invention of ever-new tactical moves in pursuit of a never-changing strategy. The long list of neoliberalism's conceptual props and related political strategies included distinguishing between public imperium and private dominium and raising the latter, like a basic human right, above the former; making different states adopt identical laws guaranteeing private property rights ('isonomy'); implanting so-called 'xenos rights' in national constitutions granting foreigners the same economic rights that they enjoyed at home; the internationalization of private law or the substitution of international private for national public law; international federations of states guaranteeing international peace while having to have a liberal economic order due to their internal heterogeneity; and common markets encompassing collections of states and obliging them to allow for unlimited competition between and within their economies, through free movement of goods and services, as well as, importantly, capital and, perhaps, labour - as enshrined in the 1990s by the European Union, in the form of the 'four freedoms' of its Internal Market. From the beginning, the outlook was decidedly global and in this sense universalistic; anything particularistic, like national states, was and is considered to be a threat to the grand design of a borderless Weltwirtschaft that was expected to restore the golden age of unbounded 19 th century liberalism.

Not that all other definitions of neoliberalism would be rendered obsolete by Slobodian's history of the neoliberal idea. ${ }^{1}$ Most of them, however, more or less deal with social and cultural adjustments to the structural condition of protected property and unprotected societies that the globalizers had in mind (and have, if perhaps only temporarily, been able to shepherd into being) that is with the base, if one wants to call it such, on which the superstructure of neoliberal culture, the 'economization' and the competitive individualism of contemporary social life, has grown. Indeed, it is only by reading Slobodian that we can fully understand the particular relationship of neoliberalism to the modern nation state, which is one of opposition and dependence at the same time - opposition to its inherent tendencies to contain and thereby distort markets, and dependence on its sovereign capacity to fend off and suppress social demands for protection that would de-liberalize the economy. The task is to weaken the nation state as an agent of economic redistribution while strengthening it as a bulwark against the illiberal dispositions of an economically unenlightened public. The critical problem here, obviously, is

1. There are quite a few of them. An inevitably incomplete selection includes Ban (2016); Bockman (2011); Brown (2015); Dardot and Laval (2013); Duménil and Lévy (2004); Foucault (2008); Konings (2018). 
democracy with its inevitably egalitarian bias, the illusions it spreads about the possibility of social justice, and its tendency to deteriorate into economic democracy at the expense of the minority of capital movers and profit shakers upon which the progress of humanity depends. Democracy, therefore, must be institutionalized in a way that prevents it from extending into domains where it does not belong, while the state must be able to patrol and enforce the institutional limits to democracy that alone make it compatible with a free economy. On this point, as on many others, Friedrich Hayek comes in with his constitutional designs, so often ridiculed, of a de-economized democracy in a deeply economistic political economy - institutional utopias that are succeeded today by the liberal rhetoric of the old, centrist-globalist "cartel parties' and their mass media against 'populism' and its claim to democratic power for the purpose of distorting the free markets of neoliberal capitalism.

On a more general level, Slobodian's book helps us clarify the critical, so often misrepresented relationship between democracy and capitalism, and the nature of neoliberalism's fragile settlement between the two. The globalists always knew that at bottom, democracy and capitalism are deadly enemies: there is no way you can have democracy under capitalism unless you manage to install a secure firewall between the two, protecting capitalism from democratic meddling. Democracy, inevitably national, can coexist with capitalism as long, and only as long, as it is restricted to the cultivation of folkloristic passions untainted by particularistic interests of class or country. Culture wars over marriage for all, passionate as they may become, are fine as long as free trade and private property in capital remain sacred. Neoliberalism, Slobodian makes clear, does not consist of releasing the capitalist economy from the state so that it can function unimpeded according to its own laws. Instead, as he puts it, liberalization means 'encasing' capitalism in state-policed institutions so that democracy cannot get to it. While this is a welcome clarification of the nature of a process that is all too often described as one of liberation - of 'market forces' but also of society as a whole - one might find it more appropriate to use the encasement metaphor for democracy rather than for the economy, the locking in, and indeed locking up, applying to democratic politics, thus preventing them from getting anywhere close to free markets and private property.

Slobodian describes the history of neoliberalism, of its doctrine and politics, as that of a group of extraordinary people - the 'globalizers': all men, densely 'networked' in space and time, in an era in which networking had not yet been invented. Self-renewing over three generations, the group held together from the end of World War I in 1918 to the creation of the World Trade Organization (WTO) in the 1990s, the high point of the rise, or return, of global capitalism. From a sociology of knowledge to a sociology of power, the history Slobodian relates is indispensable, not least for our understanding of what happened to capitalism and capitalist society in the 20th century. Although Slobodian rightly attributes importance to the people whose story he recounts, he avoids falling into the traps of conspiracy 
theory without, however, implying that there cannot be historically potent conspiracies in the real world. Such conspiracies can make history, provided that the conspirators know how to play their game, in this case a game with and between institutional positions and resources in national politics, international organizations and academia. Slobodian's globalizers were both academics and men of affairs, but academics who understood that a theory can become historically true only if it is connected to the commanding heights of politics and the economy, where power comes into its own in being exercised over the real world in cold blood.

The organizational history of neoliberalism is long and impressive, encompassing the succession of social organisms that it temporarily inhabited until it moved on to even more conducive environments. It extends from the Austrian to the International Chamber of Commerce, and from there to the rich organizational ecology of international institutions and their headquarters and research centres in Geneva, the capital of early globalism. There a university was on hand to nurture the young and provide employment to like-minded scholars from all over, including liberal emigrés from nearby Germany. All of this was close to and easily observable from Mont Pèlerin where, after World War II, Hayek assembled his sponsors and followers for his, initially hopelessly uphill, battle against Keynesianism and social democracy. Again, one cannot help but be impressed with how conscious the leaders of what Slobodian refers to as the 'Geneva School' were of the need for a firm grounding in institutional positions of power, as well as in the media and the public mind, if ultimately they were to make the world liberal again. To prevail, a long view had to be taken, and in bad times one had to go into hiding and suffer isolation and even ridicule, without letting oneself be consumed with self-doubt or despair. The only apt comparison would be with the Bolsheviks under Lenin, who were revolutionaries with a similarly stoic self-confidence and who were in many ways the only serious competitors of Hayek and his combatants until their final defeat in 1989.

Slobodian's globalizers were a sect, slowly turning into a church, of Gramscian 'organic intellectuals' the likes of which the Left has never been able to produce post-Gramsci. This was certainly true after the 1960s when world capitalism began dismantling the economic constitution of the post-war settlement in which it was kept confined as punishment for the deadly disorder it had wrought in the first half of the century. There are no indications of the sect and their leaders ever having been shaken by doubts on the worldhistorical significance of their mission, leaving them unwaveringly hopeful even in dire defeat, which they took as an opportunity to learn and regroup. Organizing was the basis of it all: seminars, meetings, university departments, collective publications, prizes for the young, making connections with sponsors while themselves sponsoring whoever might at some point prove worthy of co-optation and adoption. Differences in theory were allowed, within limits, as long as they did not call forth differences in practice, and theories were flexibly adjusted to changing circumstances. Extensive 
rotation between academia and politics, between theory and practice, was the very essence of neoliberal organization; for this the almost indefinite number of organizations and institutions around Geneva was available for acolytes of Hayek's Mont Pèlerin Society (MPS) to be placed, enriching not just them but, more importantly, the treasure of experience collectively accumulated within their brotherhood. In the end the Geneva globalizers commanded a huge number of institutions dispersed throughout the entire Western world - from the Rockefeller Foundation in New York to the GATT in Geneva and the Max Planck Institute in Hamburg. All skilfully instrumentalized in the service of defeating the democratic nation state as a would-be governor of a capitalist economy moved outside its reach by 'globalization'.

Among the many fascinating things we learn from Slobodian is the prominence of German and Austrian internationalist economists among the early globalizers, plausibly owing to their particularly painful experience after 1918 with the destruction of market-liberal empires in favour of national, and often outright democratic, statehood. We also learn how early the Right understood the full implications of the fundamental conflict between capitalism and democracy while parts of the Left were still dreaming of an international capitalism with a 'social dimension', if not a human face. Readers also learn about the closeness, above and beyond all factional disputes, between German ordoliberals of all stripes and colours and the Geneva globalizers on the one hand, and Carl Schmitt's authoritarian, strongstate anti-liberalism and anti-democratism on the other: from the globalists' global perspective the commonalities clearly outweighed the differences. In fact, far from being isolated in their defeated country, Germany's postwar ordoliberals, from Franz Böhm to Wilhelm Röpke, were a major force at the international, 'Geneva' level, just as they were surprisingly effective contributors to the rise of anti-New Deal neoliberalism in the United States that began as early as the 1950s. Those less familiar with intellectual history may also wonder about the deep involvement in neoliberal organizing and politics of someone like Ludwig von Mises, one of the great theoretical economists of his age. A market-liberal if there ever was one, he died in 1973 at the age of 92, in New York where, as Slobodian reveals, he had for decades lived in a rent-controlled apartment on the Upper West Side.

Even more exciting is Slobodian's story about the European integration project. Initially 'Europe' was contested among the neoliberals since it was not global in reach and might evolve into a regional superstate interrupting the free flow of goods, services and capital in the Weltwirtschaft. This would become the political line of Margaret Thatcher and later that of some of the Brexiteers in 2016. But others saw the European Union, in its successive incorporations, as a model of how to tame the democratic nation state through a legally enshrined supranational market, one with guaranteed property rights and an anti-interventionist competition law. That model combined isonomy 
and supranational law enforced by an international court with direct effect in national systems, thereby circumventing national legal and political systems and making them run dry - all of this building on and developing further the Hayekian federation project of the 1930s and 1940s. Even to someone who had already pointed out at length the affinity of Hayekian federalism with the European construction as of the early $2000 \mathrm{~s},{ }^{2}$ it was amazing to see how central the idea of a federation of maximally diverse countries once was to neoliberal globalism, with a free world market marketed as the price, like it or not, for international peace. Before Slobodian, it was not in any way clear to the political scientist how extensive and forward looking the neoliberal project making was from early on, to be precise from the late 1930 s, on the eve of another global war. When German ordoliberals, driven from Bonn where Konrad Adenauer despised them because of their ideological inflexibility, went to Brussels to help design the legal and institutional architecture of an integrated 'Europe', they were able to bring with them long thought-through institutional blueprints whose practical consequences and intentions hardly anyone understood apart from themselves.

Among many other things, Slobodian's book teaches us the importance of intellectual history, both for the production of new knowledge and the education of future scholars. As we read, one conceptual piece after the other falls into place and thereby reveals deep connections and connotations that we might otherwise overlook. One case in point, and only one among many, is the astonishing continuity and inner coherence of the life's work of a true polymath like Friedrich August von Hayek, on the economy, on politics, on social institutions, and on knowledge and on its origins and uses - held together by an underlying problem-cum-project that kept evolving with the historical situation and the political opportunities and constraints it entailed. Beginning with Hayek's involvement in the Viennese debates in the 1920s about socialist planning and its limits, debates in which Joseph Schumpeter and Karl Polanyi also participated, it continued in the 1930s, on the eve of World War II, as Hayek wrote about international federations that were to secure world peace while, disguised as a by-product, safely enshrining a liberal economy. Shortly before this, Hayek had dissociated himself from Konjunkturforschung (the econometric and mathematical study of the business cycle), which he found too akin to Keynesian ambitions to 'steer' the economy, letting the world know in no uncertain terms that Professor Keynes unfortunately did not have the faintest idea about economics. As Slobodian writes, Hayek himself declared the capitalist market economy to be 'sublime' and beyond human comprehension, something to be left to itself and that one interferes with at one's own risk. Hence Hayek's turn to institutionalism and the theorizing of institutional change, with an emphasis on the stickiness of institutions and the need to restrict human intervention in them 
to 'gardening' rather than 'design'. This did not prevent him from developing wide-ranging, utopian ideas about the right kind of political institutions for (neo)liberal political economies, institutions designed to keep politics off markets and protect the unknowable economy from the necessarily inept intervention in its majestic sublime self-organization by under-educated social-democratic majorities aspiring to such presumptuous objectives like social justice.

From here, at the culmination of his career as one of the most politically influential thinkers of the 20th century, Hayek arrived at his theory of 'complexity', drawing on neuropsychology and general system theory. To him this delivered the ultimate proof of the futility, and indeed frivolity, of any human attempt collectively to intervene in the course of human history, economic or otherwise, with the exception, obviously, of himself and his MPS combatants. Complexity theory à la Hayek in effect managed to defend an aristocratic social order, deeply rooted in the capitalist nature of the modern political economy, in which equality is not an end but, at best, a means to discover the very few who, by coming out on top, prove themselves to be the only ones that matter. While Hayekianism has long become the working hypothesis of neoliberalized capitalism, until now nobody has dared to draw out its implications with the frankness and the courage of its originator, and it is to Slobodian's great merit that he helps us see the connection between the admirable scholarship, on the one hand, and the sinister political project driving it, on the other. Hayek's theory of complexity, so much more sophisticated than what his fellows were able to deliver, was from its beginnings conceived to frustrate democratic-egalitarian 'socialism' and ensure that the world continued to operate according to the market principle of cumulative advantage, as summed up in, of all places, the King James Bible 'For unto every one that hath shall be given, and he shall have abundance: but from him that hath not shall be taken even that which he hath' (Matthew 25: 29). This, Hayek believed, and the neoliberals dutifully took from him, was still unendingly better than social-democratic tampering with the mysteries of a hyper-complex global capitalism. There was no discussion that one might perhaps want to look for ways of de-composing a global complexity that escapes governability, and in return trade in something like democratic self-determination and collective fate control.

An interesting question which Slobodian does not touch on - and indeed is strictly speaking not his subject — is the extent to which today's Left has bought into the globalist doctrine. By the 1990s, Third Way Social Democracy had come to accept as dogma that 'globalization', meaning open markets in an integrated world economy, was not just inevitable but outright desirable; that 'economic nationalism' was evil; and that it was the new, perhaps the last remaining, mission of nation states to open up their economies and societies to global competition while helping their citizens, within the bounds of the possible, adjust to a continuously and inescapably changing world. Recently, 'economic nationalism' has also become public 
enemy number one for a more radically internationalist non-centrist Left. That Left rallies behind a 'no border' programme it believes to be anticapitalist, unaware that the abolition of the nation state is a dream that capitalists dreamed of long before them. Several times in his book, Slobodian tries to draw a line between pro-capitalist and anti-capitalist anti-nationalism by intimating that, while his globalists on the surface professed to adhere to the same four freedoms as, for example, the British Remainers, in fact, racist as they were, they did not take the fourth freedom seriously and allowed for countries limiting or wholesale prohibiting inward migration.

Were the globalists racist? In a fascinating chapter, Slobodian reports how someone like Wilhelm Röpke, who was an outspoken opponent of Nazi Germany's anti-Semitism and who had to emigrate after Hitler's Machtergreifung (seizure of power), after World War II identified with the most disgusting racist tropes to justify South African apartheid and denounce decolonialization and majority voting in the United Nations. But, while Röpke was joined in this by some of his comrades from the MPS, Slobodian concedes that at the end this was a minority position. The globalizers' overriding goal was to abolish, if not the nation state, then its political capacity, by exposing it to a competitive world economy with safely enshrined property rights. Anything that could provoke popular opposition to this had to take second place. If immigration on a large scale threatened to wake up sleeping democratic dogs, one had better not push it. But this was for wholly pragmatic reasons, on condition that competition in global markets for goods, services and capital sufficed to do the trick and reduce nation states to sites for patriotic flag-waving nostalgia. Failing this, immigration across open borders as a universal human right under international law was kept in reserve, as an additional means to soften up national solidarity by importing the international market for labour into the national political economy. When it came down to the capitalist basics, the practical men from the MPS not only abandoned 'racist' objections to 'multiculturalism' and the like, but denounced them with much the same rhetoric as their apparent opponents on the non-centrist radical Left. ${ }^{3}$

A case in point here is the third generation Geneva-type globalizer Peter Sutherland, a multi-functionary of capital if there ever was one, who was among many other things a member of the European Commission (198589), the founding director of the WTO (1993-95), and Chairman of Goldman Sachs International (1995-2015). ${ }^{4}$ Sutherland, a lawyer from Ireland, briefly

3. Today this seems truer than ever. As the de-legitimation of economic nationalism by pointing to the alleged benefits of free trade has got stuck and the spectre of national protectionism is raising its anti-liberal head, now the abolishment of national borders is increasingly being framed as an internationalist moral obligation, with economic nationalists being denounced as xenophobes at best.

4. On Sutherland's rich vita, see the English Wikipedia: https://en.wikipedia.org/wiki/Peter _Sutherland 
appears in Slobodian's account. Giving, as director designate of the WTO, the Third Hayek Memorial Lecture, Sutherland (1994) let it be known that the new organization was based on 'two of Hayek's key insights - the role of the price system in conveying information and the importance of the rule of law' (quoted on p. 273). Slobodian also mentions Sutherland's activities as European Commissioner in charge of competition. In this capacity, according to Slobodian (p. 274), "his activism earned him the nickname "the sheriff" from Jacques Delors, because he used competition law aggressively to liberalize trade within the European Community and bring individual nations to the European Court of Justice. One scholar', Slobodian continues, 'calls him the "embodiment of neoliberal ideas in the European Commission" as he used the European Court of Justice to end state funding of national industries and ramp up competition' (ibid.).

Even more prominently, Sutherland became an activist for unrestricted immigration. As the United Nations Special Representative for International Migration (from 2006 until his death in 2017), Sutherland called upon the European Union to 'do its best to undermine the homogeneity of its member states - however difficult it may be to explain this to the citizens of those states' (quoted in Wheeler, 2012). The objective, as stated in an article written by Sutherland with the then European Commissioner for Home Affairs, Cecilia Malmström, was national or European 'competitiveness'. 5 'During the Arab revolutions', said Sutherland and Malmström (2014) 'the EU missed a historic opportunity to begin weaving together the two sides of the Mediterranean'. Today, only a few years later, technocratic population engineering from above has become politically unsustainable - exactly like the WTO's brave new free trade world after Seattle - due to popular resistance dubbed 'populist', or indeed 'racist', not just by the neoliberals but also by their left-liberal comrades-in-arms and the no-border radical Left. Now, even the more intelligent opportunists from the 1990s like Lawrence 'Larry' Summers, who was Treasury Secretary under Bill Clinton, are calling for a new, 'responsible' nationalism that includes managed trade to ensure that the benefits of open markets are more equally distributed both between and within participating countries. This begs the question whether freedom of movement of labour, the fourth of the four transnational freedoms of the neoliberal utopia, can, should and must remain standing when the three others are being pulled back into the ambit of democratic-national politics. It also raises the issue of whether socially and economically heterogeneous countries exposed to free immigration can muster the political will to fight internal inequality by protecting their societies from the vagaries of global

5. Although one does find Sutherland advocating free immigration also as a human right of the migrant, not subject to restrictions for economic reasons on the part of receiving countries. From 2015 on, Sutherland served as President of the International Catholic Migration Commission, making him a close adviser to the Holy See. 
markets. Can a country re-establish 'economic nationalism' without having control over immigration? ${ }^{6}$

After reading this exciting book, scholars who have spent part or all of their careers studying 'European integration' may want to take a step back and reflect. As wilfully neutered academics, they have for decades conscientiously analysed, applied, defined and redefined, stretched and narrowed down concepts such as multi-level government, global governance, public choice, complexity, subsidiarity and the like, taking them seriously on their face value and turning them into fashionable intellectual toys of a presentist social science entirely untroubled by its political irrelevance. Now they can understand from where those toys came to them: from a political programme so old and established that its insiders could talk about it without mentioning it. Here there was a consciousness of purpose, a desire to make history, that was so entirely alien to a stable-fed, domesticated academy, both set free and cut off from political-social responsibility, that its theories were unable to recognize it. Compared to Slobodian's globalists, the army of political scientists that specialized, mostly with funding from Brussels, in debating intergovernmentalism versus neofunctionalism, must appear hopelessly outof-step with the contemporary world around them. Indeed only a few of them, if any, ever cared about the context in which the Hayeks of this world - and how very worldly they were! - had originated concepts such as 'integration by law' or 'global governance', a context from which such concepts derived their specific spin defining them in a more than lexicographic sense, that is, in the sense that matters. Academic social science gratefully received them, as it were, as free gifts, cut off from their moorings,

6. The following figure attempts a schematic representation of the politics of the 'four freedoms':

\begin{tabular}{lll}
\hline \multicolumn{2}{c}{ The Four Freedoms } & \\
\cline { 1 - 2 } Goods, Services, Capital & Labour & \\
\hline Keep & Keep & Neoliberals ('Remainers') \\
Suspend & Keep & No-border Left (?) \\
Keep & Suspend & Liberal Centrists ('Soft Brexit') \\
Suspend & Suspend & Economic Nationalists ('Full Brexit') \\
\hline
\end{tabular}

It shows the two extreme cases, neoliberalism and economic nationalism, sandwiching two mixed cases, no-border Leftism opposing free markets for goods, services and capital, and liberal centrism ready to compromise on immigration to preserve the first three 'freedoms'. Positions in the current British debate over EU membership are introduced for purposes of illustration. Practical questions regarding the two mixed cases include: (1) whether the purpose of suspending the first three freedoms - regaining economic self-government can be realized while immigration of labour remains unregulated; (2) whether suspension of the freedom to immigrate can in fact help make the first three freedoms politically sustainable; and (3) whether the first three freedoms can in the longer run be imposed on a country without changing the composition of its population through free immigration. 
as innocent analytical constructs, l'art pour l'art, to be used as chips in value-free Glasperlenspiele (glass bead games) leading to comfortably paid, preferably tenured academic employment.

With hindsight, thanks to Slobodian, it is easy to see, although probably prohibitively uncomfortable to realize, what happened here. The 'globalizers' of Geneva and the Mont Pèlerin Society and their audience understood what they were talking about, so well that they did not always have to be explicit about it, whereas their academic epigones had no idea from which table the breadcrumbs had fallen that they spent their lives chewing on. That table was, of course, the one where the possibility of global capitalism in a world of mass democracy was being explored and denied - an issue of which the invited guests were viscerally conscious. This was not true for those deep down in their Platonian cave, where they were reduced to staring at the shadows on the PowerPoint wall in front of them, cut off from the ideas that produced them and believing capitalism to have happily been parcelled out to some other 'discipline', so they fortunately didn't have to bother with it. Taken out of context, however, their concepts, whose origins and history they wouldn't know because they thought them irrelevant, became entirely arbitrary; they could mean whatever meaning one attributed to them. To avoid attracting the disapproving eye of the next appointment committee, attributed meanings were typically nice and pleasant, that is, cleansed of any association with capitalism. 'Integration'? Good for peace. 'Social dimension'? A human face for the market. 'The four freedoms'? A better life for all, now or later. Capitalism was for the economists and their in any case too difficult mathematics - not noting that the globalizers themselves had long given up on economics, except as a propaganda tool for enlightening the unwashed about their real 'needs', austerity now for prosperity later. They had moved on to the law and political institution building as their ultimate instruments to neutralize politics and, in a world of democratic states dangerously prone to use their powers to improve the lot of the many at the expense of the few, turn the state into the Great Protector of capitalism.

\section{REFERENCES}

Ban, C. (2016) Ruling Ideas: How Global Neoliberalism Goes Local. New York: Oxford University Press.

Bockman, J. (2011) Markets in the Name of Socialism: The Left-wing Origins of Neoliberalism. Stanford, CA: Stanford University Press.

Brown, W. (2015) Undoing the Demos: Neoliberalism's Stealth Revolution. Cambridge, MA: MIT Press.

Dardot, P. and C. Laval (2013) The New Way of the World: On Neo-liberal Society. London and New York: Verso.

Duménil, G. and D. Lévy (2004) Capital Resurgent: Roots of the Neoliberal Revolution. Cambridge, MA: Harvard University Press.

Foucault, M. (2008) The Birth of Biopolitics: Lectures at the College de France, 1978-1979. London: Palgrave Macmillan. 
Konings, M. (2018) Capital and Time: For a New Critique of Neoliberal Reason. Stanford, CA: Stanford University Press.

Smith, A. (1776/1999) The Wealth of Nations: $I V-V$. London: Penguin Classics.

Streeck, W. (2014) Buying Time: The Delayed Crisis of Democratic Capitalism. London and New York: Verso Books.

Sutherland, P.D. (1994) 'A New Framework for International Economic Relations'. Third Annual Hayek Memorial Lecture, 16 June. London: The Institute of Economic Affairs.

Sutherland, P.D. and C. Malmström (2014) 'Europe's Immigration Challenge', The Guardian 24 July. www.theguardian.com/business/economics-blog/2012/jul/24/europe-immigration-chal lenge

Wheeler, B. (2012) 'EU Should “Undermine National Homogeneity" Says UN Migration Chief', $B B C$ News 21 June. www.bbc.com/news/uk-politics-18519395

Wolfgang Streeck (ws@mpifg.de) is Professor and Director Emeritus at the Max Planck Institute for the Study of Societies in Cologne, Germany. His latest publications include How Will Capitalism End? Essays on a Failing System (Verso, 2016) and Buying Time: The Delayed Crisis of Democratic Capitalism (Verso, 2014/2017). 